\title{
Risk factors for protein-energy malnutrition in pre-school shantytown children in São Paulo, Brazil
}

Departament of Pediatrics and Psychiatry, Nutrition and Metabolism Section, Universidade Federal de São Paulo, EPM - São Paulo, Brazil

\begin{abstract}
Objectives: To investigate the health and nutritional conditions of people living in a shantytown in the city of São Paulo in order to identify risk factors for infant malnutrition. Design: A retrospective cohort study. Participants: Children living in a shantytown was conducted among children less than 72 months of age. Methods: Home visits were made and information was collected regarding the risk factors for malnutrition. Results: The prevalence of chronic malnutrition was $41.6 \%$ according to Gomez, $36.6 \%$ according to Waterlow, and $17.6 \%$ according to WHO. Risk factors for malnutrition, according to the weight-for-age index, included birthweight, presence of upper respiratory tract infections, number of pregnancies, number of births, maternal body mass index, birthplace of father, and home building material; according to the weight-for-height index, they included birthweight and maternal age at the time of birth; and according to the height-for-age index, they included the number of prenatal medical visits, birthweight, maternal height, maternal body mass index, father's employment being unregistered, and maternal birthplace. An instrument for identifying children at risk of malnutrition was devised from these major risk factors for future malnutrition, which may then be applied to newly-born children.
\end{abstract}

UNITERMS: Protein-energy malnutrition. Risk factors. Pre-school.

\section{INTRODUCTION}

$\mathrm{T}$ This century has experienced an urban explosion without precedent. It is estimated that by the year 2000 half of the world's population will live in urban areas. In Brazil, the urban population is already at $75 \%$ of the total population ${ }^{(1)}$.

Along with this fact we see the growth of poor populations in cities. This implies, epidemiologically, that

\author{
Address for correspondence: \\ Alexandre A. Ferrari \\ Rua Angatuba, 492 - Pacaembu \\ São Paulo/SP - Brasil - CEP 01247.000
}

there is an increase in new risks for the health and nutrition of this population, due to the appearance of pathologies peculiar to urban life, an increase in the cost of basic necessities, and a decrease in survival strategies ${ }^{(2)}$. Proteinenergy malnutrition is generally a major contributor to morbidity in these pockets of poverty.

According to the World Health Organization (WHO), more than $30 \%$ of the world's infant population is malnourished ${ }^{(3)}$. In our country the prevalence of chronic malnutrition varies, according to data from the National Health and Nutrition Survery (PNSN), between $8.1 \%$ and $27.3 \%$, depending on the region studied ${ }^{(4)}$.

Despite ample research and the emergence of methods able to combat malnutrition, it continues to be a challenge for health-care workers due to the multifactorial causes of this pathology. Methods used to eliminate malnutrition, such as the distribution of food, have been shown to have a low 
efficacy in meeting even basic needs, possibly suggesting that these efforts are more political than medical or social. In addition, health-care professionals who work directly with these patients deal with the reality and difficulty of executing successful interventions.

The study of risk factors, proposed by WHO in the $1970 \mathrm{~s}^{(5)}$ continues to be a methodology capable of assisting in the war against malnutrition, through health-care services. It often happens that these services are not organized to meet the real needs of the community they serve, leaving individuals at greatest risk with the least amount of attention (6). Still, the identification of the risk factors is useful for the prevention of disease by improving the knowledge of the causal chain. In fact, those risk factors that are part of a causal pathway allow for primary preventive actions; moreover, those with recognized associations, but not part of the causal pathway, may provide secondary prevention.

\section{OBJECTIVES}

The present study was designed with the objective of investigating the health and nutritional conditions of people living in a shantytown in the city of São Paulo in order to identify risk factors for infant malnutrition that could be used in health promotion programs.

\section{METHODS}

We designed a retrospective cohort study with children from 0 to 72 months of age living in a shantytown of approximately 3500 inhabitants, located within an upper-class neighborhood of São Paulo. Children from the shantytown were invited to undergo anthropometric measurements at two sites, each with easy access from the shantytown. 233 children, $33.3 \%$ of the total shantytown population according to a preliminary survey, responded to the invitations and were then studied. In subsequent home-visits, each child's mother or guardian responded to a questionnaire specific to risk factors for malnutrition. The variables studied are listed in Table 1.

The anthropometric measurements were conducted by the same investigators according to the methodology proposed by Jelliffe ${ }^{(7)}$. After recording general data for each child, he/she was weighed on a Filizola digital scale, with precision $\pm 10 \mathrm{~g}$, that was zeroed after each weighing. The children were weighed in their undergarments and infants were weighed without diapers. Children older than 2 years of age had their heights measured against a wall, without shoes, and under a ruler, fixed against the wall with the assistance of a level which allowed for the head to be positioned at a $90^{\circ}$ angle. Children less than 2 years of age were measured with a wooden anthropometer in a horizontal position. The mothers were weighed during the home visits, with portable bathroom scales, wearing light clothing (a skirt or pants with a shirt), and measured with a vertical ruler fixed to the wall. Malnourished children were referred to a medical exam to determine which cases had secondary malnutrition and to initiate nutritional treament.

We used EPI-Info to create and analyze the nutritional data bank and the National Center for Health Statistics (NCHS) as the standard reference bank to study the relationship of these variables to the nutritional state. We defined as malnourished those children who presented a $\mathrm{z}$-score less than -2.0 for the indexes weight-for-age (W/ A) and height-for-age (H/A) and -1.0 for weight-for-height $(\mathrm{W} / \mathrm{H})$.

Table 1

Variables Related to Protein-Energy Malnutrition

\begin{tabular}{lll}
\hline Child & Parents & Environmental Demographics \\
Age & Obstetric history & Origin of water used \\
Sex & Maternal weight and height & Type of sewage system \\
Time between births of siblings & Maternal body mass index & Structure of toilets \\
Age of Mother at time of birth & Presence of father & Construction material for house \\
Number of Pre-Natal Clinical Visits & Age of mother and father & Number of persons living in house \\
Fetal maturity at birth & Time parents have lived within the & Ratio of no. of tenants / no. of wage \\
Birthweight and birthorder & city limits & earners in the home \\
Breastfeeding practices & Educational level of parents & \\
Immunization of Child & Occupation of parents & \\
Illnesses & Type of employment of parents \\
& Maternal and paternal birthplace & \\
\hline
\end{tabular}


Table 2

Prevalence of Malnutrition

\begin{tabular}{lccccc}
\hline GOMEZ & Freq.\% & WATERLOW & Freq.\% & OMS & Freq.\% \\
\hline $3^{\text {rd }}$ Degree & 0.5 & "wasted" & 2.2 & "wasted" & 0.4 \\
$2^{\text {nd }}$ Degree & 3.1 & "stunted" & 36.6 & "stunted" & 17.6 \\
$1^{\text {st }}$ Degree & 38 & "wasted-stunted" & 5.2 & "low-weight" & 7.7 \\
\hline
\end{tabular}

Table 3

Risk factors, risk cutoff levels and frequency (\%) of appearance (prevalence or incidence)

\begin{tabular}{|c|c|c|}
\hline Variable & Risk cutoff level $\mathrm{F}$ & Freq. $(\%$ \\
\hline Age group & $<24$ months & 36.6 \\
\hline Sex & masculine & 51.2 \\
\hline Birth order & first born & 37.2 \\
\hline Pre-natal exams & none & 14.8 \\
\hline No. pre-natal exams & $\leq 5$ & 42.5 \\
\hline Birthweight & $<2500 \mathrm{~g}$ & 19 \\
\hline Age of mother at time of birth & $\leq 18$ or $\geq 35$ yrs & 26.2 \\
\hline Time between births & $\leq 24$ months & 50.8 \\
\hline Fetal maturity at birth & premature & 2.4 \\
\hline Use of artifical food & before 6 months & 78.9 \\
\hline Cessation of breastfeeding & before 6 months & 62 \\
\hline Immunization & late & 9.9 \\
\hline URT Infections & present & 32 \\
\hline Diarrhea & present & 5.2 \\
\hline No. of pregnancies & $>$ than 4 & 32.1 \\
\hline No. of births & $>$ than 4 & 26.4 \\
\hline No. of abortions & 1 or more & 23.9 \\
\hline Maternal weight & $<50$ or $>70 \mathrm{~kg}$ & 37.4 \\
\hline Maternal height & $<150 \mathrm{~cm}$ & 28.3 \\
\hline Body mass index & $<20.0 \mathrm{Kg} / \mathrm{m}^{2}$ & 15.2 \\
\hline Maternal age & $\leq 18$ years & 5.4 \\
\hline Paternal age & $\leq 18$ years & 3.5 \\
\hline Father & absent & 22.3 \\
\hline Educational level of father & less than 2 years & 37.2 \\
\hline Educational level of mother & less than 2 years & 37.8 \\
\hline Occupation of mother & none & 54.5 \\
\hline Type of employment of mothe & temporary & 75.9 \\
\hline Occupation of father & none & 17.2 \\
\hline Type of employment of father & temporary & 44.8 \\
\hline Birthplace of mother & this state & 21.6 \\
\hline Birthplace of father & this state & 12.6 \\
\hline Time mother has been in SP & more than 10 years & s 44.5 \\
\hline Time father has been in SP & more than 10 years & 44.6 \\
\hline No. of persons in home & $\geq 8$ & 11.8 \\
\hline No. tenants/no. employed & more than 2 & 81.8 \\
\hline Use of water & with other families & 10 \\
\hline Use of toilet & with other families & 14.8 \\
\hline Fate of human waste & open air & 49.5 \\
\hline Home building material & wood & 63.6 \\
\hline
\end{tabular}

Statistically significant associations were determined through chi square tests $\left(\mathrm{c}^{2}\right)$ and Fisher's exact test. The variables were divided into two groups, exposed and unexposed to risk, using cut-off levels of risk as proposed in the literature. The null hypothesis was rejected when $\mathrm{p}<0.05$.

Finally, the variables found to be statistically associated with malnutrition served to identify the population of individuals with the greatest chance of becoming malnourished. These individuals were targeted by health-care workers in this population in an effort to decrease the high prevalence of disease. For this, we used the variables that were associated with chronic malnutrition (H/A).

The instrument necessary for the completion of such a task is a numerical score related to the presence of risk factors. Each risk factor that a subject has gives him/her a point score proportional to the relative risk for that factor. The sum of these points is the total score achieved for each subject. The relative risk (RR) can itself be used for scoring with this instrument. However, as this instrument can be used by health-care workers with only minimal education, each RR can simply be converted to a whole number. Another method of accomplishing this is to convert the RR into its logarithm (Table 4), according to the method proposed by OPAS ${ }^{(6)}$.

After determining the total score for each child, we calculated the sensitivity and specificity of the instrument for nutritional diagnoses for each subject and the corresponding final total score (Table 5).

\section{RESULTS}

The prevalence of malnutrition in this population varied depending on the criterion used (Table 2).

The prevalences and incidences of risk factors studied are presented in table 3 . The relative risk (RR) varied according to the index used (Table 4). Knowing the RR of each statistically associated risk factor for chronic 
Table 4

Risk factors, relative risks (RR) for malnutrition according to the indexes weight/age (W/A), weight/height $(\mathrm{W} / \mathrm{H})$ and height/age $(\mathrm{H} / \mathrm{A})$ and respective confidence interval (C.I.) and ' $\mathrm{p}$ '.

\begin{tabular}{|c|c|c|c|c|c|c|c|c|c|}
\hline \multicolumn{3}{|c|}{ W/A } & \multicolumn{3}{|c|}{$\mathrm{W} / \mathrm{H}$} & \multicolumn{4}{|c|}{$\mathrm{H} / \mathrm{A}$} \\
\hline Variable & $-\mathrm{RR}-$ & C.I. & $-p-$ & -RR- & C.I. & $-p-$ & $\mathrm{RR}$ & C.I. & $-p-$ \\
\hline Age group & 0.47 & $0.14-1.63$ & NS & 0.53 & $0.18-1.56$ & NS & 1.07 & $0.58-1.99$ & NS \\
\hline Sex & 1.27 & $0.46-3.51$ & NS & 1.36 & $0.54-3.42$ & NS & 1.36 & $0.74-2.52$ & NS \\
\hline Birth order & 0.94 & $0.33-2.68$ & NS & 1.50 & $0.61-3.69$ & NS & 0.92 & $0.49-1.73$ & NS \\
\hline Pre-natal exams & 0.48 & $0.07-3.53$ & NS & 0.82 & $0.20-3.40$ & NS & 1.03 & $0.44-2.4$ & NS \\
\hline No. pre-natal exams & 0.85 & $0.29-2.47$ & NS & 0.81 & $0.31-2.13$ & NS & 1.84 & $0.99-3.41$ & * \\
\hline Birthweight & 5.97 & 2.04-17.53 & *** & 5.69 & $2.13-15.17$ & ** * & 2.47 & $1.32-4.62$ & * * \\
\hline Age of mother at time of birth & 2.42 & $0.86-6.00$ & NS & 2.82 & $1.13-7.06$ & * & 0.90 & $0.44-1.85$ & NS \\
\hline Time between births & 0.97 & $0.25-3.70$ & NS & 0.32 & $0.07-1.54$ & NS & 1.26 & $0.60-2.65$ & NS \\
\hline Fetal maturity at birth & 3.70 & $0.62-22.21$ & NS & 3.13 & $0.53-18.51$ & NS & \# & \# & \# \\
\hline Use of artifical food & 3.47 & $0.47-25.63$ & NS & 1.24 & $0.38-4.10$ & NS & 1.55 & $0.64-3.71$ & NS \\
\hline Cessation of breastfeeding & 2.25 & $0.65-7.76$ & NS & 1.47 & $0.54-3.99$ & NS & 0.99 & $0.53-1.84$ & NS \\
\hline Immunization & 2.47 & $0.76-7.99$ & NS & 0.57 & $0.08-4.01$ & NS & 1.94 & $0.94-4.01$ & NS \\
\hline URT Infections & 2.84 & $1.03-7.78$ & * & 1.89 & $0.77-4.64$ & NS & 1.49 & $0.81-2.72$ & NS \\
\hline Diarrhea & 1.39 & $0.20-9.50$ & NS & 1.13 & $0.17-7.61$ & NS & \# & \# & \# \\
\hline No. of pregnancies & 3.03 & $1.04-8.86$ & * & 1.14 & $0.44-2.97$ & NS & 0.95 & $0.49-1.82$ & NS \\
\hline No.of births & 3.09 & $1.10-8.72$ & * & 1.21 & $0.44-3.28$ & NS & 0.85 & $0.41-1.74$ & NS \\
\hline No. of abortions & 1.57 & $0.51-4.82$ & NS & 2.12 & $0.83-5.46$ & NS & 0.49 & $0.18-1.30$ & NS \\
\hline Maternal weight & 2.91 & $1.00-8.46$ & * & 0.91 & $0.33-2.53$ & NS & 1.39 & $0.73-2.64$ & NS \\
\hline Maternal height & 1.68 & $0.58-4.85$ & NS & 0.67 & $0.20-2.27$ & NS & 2.06 & $1.10-3.86$ & 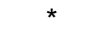 \\
\hline Body mass index & 3.78 & $1.36-10.50$ & 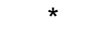 & 0.93 & $0.23-3.84$ & NS & 3.02 & $1.64-5.57$ & * * \\
\hline Maternal age & \# & \# & \# & \# & \# & \# & 1.72 & $0.53-5.56$ & NS \\
\hline Paternal age & 4.85 & $0.87-27.10$ & NS & 3.64 & $0.67-19.70$ & NS & 1.75 & $0.34-8.99$ & NS \\
\hline Father & 1.62 & $0.54-4.86$ & NS & 1.25 & 0.43-3.59 & NS & 1.25 & $0.62-2.51$ & NS \\
\hline Educational level of father & 0.72 & $0.15-3.55$ & NS & 1.44 & $0.41-5.07$ & NS & 1.24 & $0.58-2.67$ & NS \\
\hline Educational level of mother & 1.80 & $0.66-4.90$ & NS & 2.03 & $0.83-4.99$ & NS & 0.98 & $0.52-1.85$ & NS \\
\hline Occupation of mother & 0.89 & $0.33-2.43$ & NS & 1.27 & $0.51-3.19$ & NS & 1.00 & $0.55-1.83$ & NS \\
\hline Type of employment of mothe & $\operatorname{er} 1.24$ & $0.30-5.18$ & NS & 0.70 & $0.17-2.92$ & NS & 1.19 & $0.49-2.90$ & NS \\
\hline Occupation of father & 0.53 & $0.07-3.97$ & NS & 0.4 & $0.05-2.90$ & NS & 0.86 & $0.33-2.28$ & NS \\
\hline Type of employment of father & r 1.66 & $0.47-5.84$ & NS & 2.08 & $0.72-6.02$ & NS & 2.08 & $0.99-4.35$ & \\
\hline Birthplace of mother & 1.24 & $0.35-4.35$ & NS & 1.55 & $0.58-4.12$ & NS & 2.55 & $1.40-4.65$ & ** \\
\hline Birthplace of father & 4.09 & $1.20-13.93$ & $\star$ & 2.86 & $0.9-9.10$ & NS & 0.38 & $0.06-2.59$ & NS \\
\hline Time mother has been in SP & 1.84 & $0.61-5.57$ & NS & 1.48 & $0.6-3.65$ & NS & 1.49 & $0.80-2.78$ & NS \\
\hline Time father has been inSP & 1.43 & $0.38-5.48$ & NS & 1.19 & $0.38-3.71$ & NS & 1.30 & $0.60-2.85$ & NS \\
\hline $\mathrm{N}^{\circ}$ of persons in home & 1.08 & $0.26-4.52$ & NS & 0.86 & $0.21-3.53$ & NS & 1.39 & $0.65-2.98$ & NS \\
\hline $\mathrm{n}^{\circ}$ tenants $/ \mathrm{n}^{\circ}$ employed & 0.62 & $0.19-2.08$ & NS & 0.55 & $0.20-1.56$ & NS & 1.28 & $0.49-3.31$ & NS \\
\hline Use of water & 1.88 & $0.47-7.58$ & NS & 2.42 & $0.79-7.42$ & NS & 1.50 & $0.62-3.66$ & NS \\
\hline Use of toilet & 2.33 & $0.69-7.94$ & NS & 2.55 & $0.89-7.27$ & NS & 1.00 & $0.39-2.57$ & NS \\
\hline Fate of human waste & 0.84 & $0.31-2.33$ & NS & 0.79 & $0.31-1.97$ & NS & 0.89 & $0.48-1.63$ & NS \\
\hline Home building material & 3.96 & $0.92-17.15$ & & 1.58 & $0.58-4.30$ & NS & 1.83 & $0.91-3.68$ & NS \\
\hline
\end{tabular}

* $: p<=0.05$

$\star *: p<=0.01$

*** $: p<=0.001$

NS: non significant

\# : there were no malnourished children in the risk group considered

malnutrition (H/A), these were converted to points, according to Table 5: 5 or less pre-natal examinations, $\mathrm{RR}=1.84$ ( 3 points); birthweight less than $2500 \mathrm{~g}, \mathrm{RR}=2.47$ (5 points); maternal height less than $150 \mathrm{~cm}, \mathrm{RR}=2.06$ (4 points); maternal body mass index less than $20 \mathrm{~cm} / \mathrm{kg}^{2}$, $\mathrm{RR}=3.02$ (5 points); father's employment being unregistered, $\mathrm{RR}=2.08$ (4 points); mother born in São Paulo, $R R=2.55$ (5 points).

Table 6 presents the sensitivity and specificity for the different groups of point scores for nutritional diagnoses of each subject and the corresponding final total score.

\section{DISCUSSION}

Classifying malnutrition according to the three leading methods leads us to different conclusions. For example, Gomez classified malnutrition according to the risk of death for a determined illness, demonstrated to be twice as great in moderately malnourished persons and three times greater in severely malnourished persons. Using this criterion, Monteiro, in the city of São Paulo, reported the prevalence of mild malnutrition to be $25.9 \%{ }^{(8)}$, 
while the population in this study had a level of $38 \%$, similar to levels in the poorest rural areas of the country.

Verifying the classification of Waterlow we note that stunting, found to have a prevalence of $36.6 \%$, is the largest public health problem among the urban poor. The physical process of stunting apparently provides energy for basic survival by conserving energy normally used in the growth process.

Finally, the prevalence of malnutriton according to WHO also varied according to the index used. H/A, which gives us the best information about the frequency of chronic malnutrition, was $17.6 \%$, slightly greater than the $15.4 \%$ found in the PNSN during the latter part of the $1980 \mathrm{~s}^{(4)}$. W/H, which informs us of a recent loss of weight or a mild form of malnutrition, revealed a prevalence less than in the reference study: $0.4 \%$ versus $2 \%$, respectively. The index W/A, which carries information from both of the previous two indexes, demonstrated a prevalence of malnutrition of $7.7 \%$, similiar to the national level.

In one study ${ }^{(3)}$ the worldwide prevalence of infant malnutrition in the developing world was reported to be $42.7 \%, 9.2 \%$, and $35.8 \%$ for $\mathrm{H} / \mathrm{A}, \mathrm{W} / \mathrm{H}$, and $\mathrm{W} / \mathrm{A}$, respectively. National studies concerning Latin America found minor levels of malnutrition (less than $20 \%$ for $\mathrm{H} /$ $\mathrm{A}$, less than $4 \%$ for $\mathrm{W} / \mathrm{H}$, and less than $10 \%$ for $\mathrm{W} / \mathrm{A}$ ), making low $\mathrm{H} / \mathrm{A}$ the most prevalent form of malnutrition. It is worth noting that the prevalence of malnutrition in Brazil is classified as "mild", as proposed by WHO, when compared to other developing countries. However, when $\mathrm{H} / \mathrm{A}$ is used as the index for malnutrition, our country has approximately 7 times more malnourished people than would be expected in areas with adequate health care.

In addition, the pattern of malnutrition among the study population was manifested by stunting rather than by severe malnutrition, which is more often seen among the poor living in rural areas. It is also important to note that these people, despite living in urban areas, with all of the benefits that recent urbanization provides, are still living in a situation that does not provide for the proper development of the individual.

We were also able to learn more about social characteristics of this population. For example, all of the individuals living in this shantytown, were presumed to come from the same social class. Nevertheless, within this social class there seems to exist a certain stratification characterized by low paternal and maternal education (37.2\% and $37.8 \%$, respectively), unemployment (17.2\% of parents were not working), homes made from wood (63.6\%), and open sewers (49.5\% of cases). Also, the variables for health indicated that low health education is a common problem: $42.5 \%$ did not received adequate pre-
Table 5

Conversion of relative risks to risk scores

\begin{tabular}{cccccc}
\hline RR & $\log 10$ & points & RR & $\log 10$ & points \\
\hline 1.0 & 0 & 1 & 3.0 & 0.48 & 5 \\
1.2 & 0.08 & 2 & 4.0 & 0.60 & 6 \\
1.4 & 0.15 & 2 & 5.0 & 0.70 & 7 \\
1.6 & 0.20 & 3 & 6.0 & 0.78 & 8 \\
1.8 & 0.26 & 3 & 7.0 & 0.85 & 9 \\
2.0 & 0.30 & 4 & 8.0 & 0.90 & 9 \\
2.2 & 0.34 & 4 & 9.0 & 0.95 & 10 \\
2.5 & 0.40 & 5 & 10.0 & 1.0 & 10 \\
\hline
\end{tabular}

Table 6

Distribution of population according to "total risk score", with respective sensitivities and specificities

\begin{tabular}{cccccc} 
SCORE & maln & hlth & total & Sn & Sp \\
\hline 0 & $\mathrm{n}^{-}$ & $\mathrm{n}^{-}$ & $\mathrm{n}^{-}$ & $\%$ & $\%$ \\
3 & 4 & 37 & 41 & 88.2 & 26.8 \\
4 & 5 & 20 & 25 & 73.5 & 41.3 \\
5 & 0 & 17 & 17 & 73.5 & 53.6 \\
7 & 2 & 12 & 14 & 67.6 & 62.3 \\
8 & 0 & 10 & 10 & 67.6 & 69.5 \\
9 & 1 & 11 & 12 & 64.7 & 77.5 \\
10 & 3 & 10 & 13 & 55.9 & 84.7 \\
11 & 2 & 1 & 3 & 50 & 85.4 \\
12 & 0 & 2 & 2 & 50 & 86.8 \\
13 & 9 & 8 & 17 & 23.5 & 92.6 \\
14 & 0 & 8 & 8 & 23.5 & 98.4 \\
16 & 2 & 0 & 2 & 17.6 & 98.4 \\
17 & 2 & 1 & 3 & 11.7 & 99.1 \\
18 & 1 & 0 & 1 & 8.8 & 99.1 \\
21 & 0 & 1 & 1 & 8.8 & 100 \\
23 & 1 & 0 & 1 & 5.9 & 100 \\
26 & 1 & 0 & 1 & 3 & 100 \\
TOTAL & 1 & 0 & 1 & 0 & 100 \\
\hline
\end{tabular}

maln=malnourished; hlth=healthy; Sn=sensitivity; $\mathrm{Sp}=$ specificity

natal care, $19 \%$ of the children had low birthweight - the national prevalence is $8.3 \%$, according to Nóbrega ${ }^{(9)}-50.8 \%$ of the cases had an inadequate childbirth interval, and 79.5\% stopped breastfeeding within the first 6 months of life.

To find markers of malnutrition in this shantytown we looked for the following: birthweight, presence of upper respiratory tract infections, number of pregnancies, number of births, maternal body mass index, birthplace of father, and home building material for the weight-forage index; birthweight, and maternal age at the time of birth for the weight-for-height index; number of pre-natal 
medical visits, birthweight, maternal height, maternal body mass index, father's employment being unregistered, and mother's birthplace for the height-for-age index.

The objective of identifying markers for malnutrition from various etiologies within a population is in its contribution to prevention programs. In our cases we had to take account of reference markers that were found in three different indexes, each expressing a different combination of biological processes.

The index H/A reflects linear growth and a deficiency in growth indicates long-term inadequacies in health and nutrition. It used to be believed that for children older than 2 years of age, deficits in H/A indicated past nutritional deficiencies. More recent work suggests that stunting is not a permanant disorder, with little or no hope for recovery, for children older than 2 years ${ }^{(10,11)}$.

The index $\mathrm{W} / \mathrm{H}$ reflects the corporal weight in relation to height, and may be calculated without knowing the age of the child. Normally, W/H indicates an important, recent process which has prompted a loss of weight. The low prevalence of malnutrition, according to this index, does not necessarily indicate the absence of nutritional problems in a population: the common use of the term "nutritional dwarfism" serves to remind us of this. In our country, Victora ${ }^{(12)}$ suggested that H/A is the best index for studying the prevalence of malnutrition, since in a Latin-American population, due to possible physicalethnic differences, the $\mathrm{W} / \mathrm{H}$ is much less adaptable than in other populations of the world.

Finally, the W/A tells us about the corporal mass in relation to chronological age. Since W/A is influenced as much by the weight as by the height, it can be difficult to interpret. In communities with low levels of acute malnutrition (defined by W/H) W/A is is highly correlated with $\mathrm{H} / \mathrm{A}$, i.e. long-term health. On the other hand, if W/A changes quickly, it is most often due to rapid changes in weight.

The index to be used depends on the goal to be achieved. For example, an educational program should be aimed at those individuals exposed to chronic illnesses, while emergency measures should focus on acute illnesses.
Taking into consideration the characteristics of the urban poor and their lack of education in basic health, we devised an instrument using the risk factors for malnutrition according to H/A, that proved to be simple and useful.

If our goal in a community is to prevent a great number of children from becoming malnourished, we could choose a total score of 3 as a cutoff, considering at risk all those with one or more factors for malnutrition. For this we would use an examination with a sensitivity of $73.5 \%$. On the other hand, if our objective is to optimize the clinical visits, prioritizing those who have the greatest needs, we could choose 13 points as the cutoff level. This would allow $98.4 \%$ of those considered healthy to be identified, allowing us to treat only those considered to be at the greatest risk of malnutrition.

Thus, by identifying these risk factors for malnutrition, which can easily identify the children who are most likely to become malnourished, we have designed a diagnostic tool that can easily be employed in field or clinical settings. It is interesting that the risk factors found are already identifiable at the birth of the child. From the first contact with a team of health workers, those with the greatest risk could receive preferential treatment. Also, with changes in the standard of care offered by different groups of health care workers, the instrument could be changed according to the objectives, by altering the cutoff level. The importance of this tool is that any health-care worker could assess a child's risk of future malnutrition with minimal effort and a large degree of accuracy. This would allow for early intervention to be directed towards those children with the greatest need.

\section{CONCLUSION}

Risk factors associated with malnutrition in a specific community allow for the development of alternative methods to combat this pathology, characteristic of our larger cities. 


\section{RESUMO}

Objetivos: Conhecer a situação de saúde e nutrição de uma população favelada da cidade de São Paulo e identificar fatores de risco para a desnutrição infantil. Desenho: Estudo de corte retrospectivo. Participantes: Favelados menores de 72 meses de idade. Métodos: Foram feitas visitas domiciliares e colhidas informações acerca de fatores de risco para a desnutrição. Resultados: A prevalência segundo Gomez foi de 41,6\%; para a desnutrição crônica encontraram-se níveis de $36,6 \%$, segundo Waterlow, e de $17,6 \%$ segundo a OMS. Os fatores de risco de desnutrição segundo o índice peso/idade foram 'peso de nascimento', 'infecção atual em vias aéreas superiores', 'no de gestações', 'no de partos', 'índice de massa corpórea da mãe', 'naturalidade paterna' e 'material de construção da casa'; para o índice peso/estatura foram 'peso de nascimento' e idade materna ao parto'; para o índice estatura/idade 'número de consultas no pré-natal', 'peso de nascimento', 'estatura materna', 'índice de massa corpórea da mãe', 'o pai não ser registrado no trabalho' e 'naturalidade materna (mães nascidas em São Paulo)'. Construiu-se um instrumento para a triagem daqueles sob maior risco para desnutrição futura, possível de ser aplicado já entre recém-nascidos.

\section{REFERENCES}

1. Organizacion Panamericana de la Salud. Brasil. In: Las condiciones de Salud en las Americas. Publicación científica No. 549, vol.2 p.87-100, Washington D.C.,1994.

2. Monteiro CA. Saúde e nutrição das crianças de São Paulo. Diagnóstico, contrastes sociais e tendências. São Paulo: HUCITEC/Edusp; 1988 p.165.

3. Onís M, Monteiro C, Akré J, Clugston G. The worldwide magnitude of protein-energy malnutrition: an overview from the WHO global database on child growth. Bull World Health Organization, 1993; 71(6):703-712.

4. IBGE. Crianças e adolescentes: indicadores sociais. IBGE, CDDI, Rio de Janeiro, 1992 p.159.

5. World Health Organization. Risk approach for maternal and child health care. Geneve, 1978. WHO Offset Publication, No. 39.

6. Organizacion Panamericana De La Salud. El enfoque de riesgo en la atención a la salud. In: Manual sobre el enfoque de riesgo en la atención maternoinfantil. Serie PALTEX para ejecutores de programas de salud, 1986; No.7:9-24.
7. Jelliffe DB. Evaluación del estado de nutrición de la comunidad. Genebra, Organizacion Mundial de la Salud, 1968. 201p. (serie de monografías, 53).

8. Monteiro CA. Estudo das condições de saúde das crianças do Município de São Paulo, SP (Brasil), 1984-1985 II Antropometria Nutricional. Rev Saúde Públ 1986; 20(6):446-53.

9. Nóbrega FJ, Vítolo MR, Brasil ALD, Lopez FA. Condição nutricional de mães e filhos: relação com o peso ao nascimento, variáveis maternas e sócio-econômicas. Jornal de Pediatria, 1991, 67(9/10):288-296.

10. Morais MB, Ferrari AA, Fisberg M. Effect of oral iron therapy on physical growth. São Paulo Med Jour, 1993; 111(6):439-44

11. Vieira MFA. Avaliação da recuperação de crianças desnutridas atendidas pelo Centro de Recuperação e Educação Nutricional (CREN) - Tese de Mestrado apresentada ao curso de pós-graduação em Nutrição da UNIFESP - São Paulo, 1996.

12. Victora CG. The association between wasting and stunting: an international perspective. J Nutr 1992; 122:1105-1110. 